\title{
FERTIRRIGATION OF CANAVALIA ENSIFORMIS USING DIFFERENT DOMESTIC WASTEWATER CONCENTRATIONS
}

\author{
MALAFAIA, G. ${ }^{1,2}$; BATISTA, M.A. ${ }^{1}$; LIMA, F.C. ${ }^{1}$; LIMA, M.L.P.'; ARAÚJO, F.G. ${ }^{1}$; RODRIGUES, A.S.L. ${ }^{1}$; \\ MOZENA, W.L. ${ }^{2}$; CUNHA, P.P. ${ }^{2}$; COSTA, R.B. ${ }^{2} \&$ XIMENES, P.A. ${ }^{2}$ \\ 1 - Instituto Federal Goiano - Campus Urutaí, Rodovia Geraldo Silva Nascimento km 2,5 - Zona \\ Rural - Urutaí, Goiás, Brazil. \\ 2 - Postgraduate Program in Agronomy, School of Agronomy, Universidade Federal de Goiás (UFG), \\ Goiânia, Goiás, Brazil. \\ *Corresponding author: e-mail: guilhermeifgoiano@gmail.com
}

\begin{abstract}
Malafaia, G.; Batista, M.A.; Lima, F.C.; Lima, M.L.P.; Araújo, F.G.; Rodrigues, A.S.L.; Mozena, W.L.; Cunha, P.P.; Costa, R.B. \& Ximenes, P.A. (2014) Fertirrigation of Canavalia ensiformis using different domestic wastewater concentrations. Braz. J. Aquat. Sci. Technol. 18(1):25-32. eISSN 1983-9057. DOI: 10.14210/bjast.v18n1.p25-32 This study assessed the growth of Canavalia ensiformis (used as green manure), irrigated with different concentrations of wastewater. We evaluated the early, vegetative and reproductive development of the species. The experimental designs were completely randomized with five treatments and 30 repetitions (for the evaluation of early development) and 8 repetitions (for the evaluation of the vegetative and reproductive development). Five groups were established: A $100-100 \%$ of water supply, L100 - 100\% of water coming from a stabilization pond for domestic sewage, L75, L50 and L25 - mixtures of supply water and wastewater from the stabilization pond ( $25-75 \%, 50-50 \%$ and $75-25 \%$, respectively). The results show that the treatments did not affect the initial development of the species, since no differences were observed between groups, when comparing variable germination speed index (GSI), germination mean time (GMT), germination rate (GR), seedling length and dry weight. On the other hand, the L100 and L75 groups had higher shoot length, total number of leaves, stem diameter, number of branches and pods produced. The number of flower buds was higher in group L100. Regarding the fresh biomass and dry areas of the aerial parts, roots and total phytomass, the L100 and L75 groups showed statistically higher values. It is concluded that the best plant growth occurred in groups L100 and L75, with fertirrigation containing $100 \%$ and $75 \%$ wastewater, respectively.
\end{abstract}

Keywords: Wastewater. Non-agricultural species. Environmental preservation.

\section{INTRODUCTION}

When it comes to drinkable water, the discharge of domestic sewage is among the anthropic activities that have contributed to the depletion of this resource, because such effluents are almost always discharged in rivers, lakes and other water bodies after being inefficiently treated or even untreated. In this sense, the reuse of domestic wastewater has been considered an important practice to minimize the negative impacts caused by its discharge in natural water resources. Among the reuse practices, fertirrigation with wastewater derived from domestic sewage has been applied, in particular in arid and semi-arid regions (Sousa et al., 2006; Souza et al, 2010a; Santos, 2011; Silva et al., 2012; Azevedo et al., 2013; Vale et al., 2013; Oliveira et al., 2013a,b). One of the advantages of such practice is sparing drinkable water.

Several studies have shown that the use of domestic wastewater in agriculture can also increase productivity (Azevedo, et al. 2007; Alves et al., 2009ab; Nascimento et al., 2009; Costa et al., 2009; Silva et al., 2012; Azevedo et al., 2013; Vale et al., 2013; Oliveira et al., 2013a,b). As discussed by Hespanhol (2003), irrigation with water coming from domestic sewage reduces substantially or even eliminates the use of commercial fertilizers in soils prepared for agricultural and non-agricultural plantations. As the domestic effluents contain nutrients, their application can, in the long term, promote the addition of organic matter, which acts as a conditioner, increasing the capacity of the soil to retain water.

In general, there are no chemical restrictions regarding the quality of domestic wastewater for fertirrigation, being the effects of such practice on the development of different plant species the subject of many studies (Nery Rodrigues et al., 2009; Rebouças, 2010; Souza et al., 2010b; Santos-Junior, 2011; Javarez-JR et al., 2010; Damasceno et al., 2011; Mota et al., 2011; Sampaio et al., 2011; Lacerda et al., 2011; Silva et al., 2012; Azevedo et al., 2013; Vale et al., 2013; Oliveira et al., 2013a,b).

For several reasons, the reuse of treated or partially treated effluents in fertirrigation has been an attractive alternative to the discharge of these effluents in water bodies (Santos et al., 2006). Some of the reasons are: (i) wastewater from domestic sewage can become a supplementary water source to promote sustainable agriculture, especially in regions where water is scarce; (ii) within some limitations, the use of wastewater can also make other resources available, such as those related to the nutritional aspects of the 
plants, and (iii) wastewater use not only helps preserve the quality of superficial waters, but also its "disposal" on the soil implies recycling, in the sense that "pollutants" become nutrients for plant growth (Hespanhol, 2003; Barroso \& Wolff, 2011).

In this context, the aim of the present study is the assessment of the effect of fertirrigation with different concentrations of wastewater coming from a domestic sewage stabilization pond on the development of Canavalia ensiformis (jack bean).

\section{MATERIALS AND METHODS}

The present study was carried out in a greenhouse located in the Federal Institute of the State of Goiás (Instituto Federal Goiano) - at Urutaí (State of Goiás, Brazil). Canavalia ensiformis (jack bean) is an annual-cycle, herbaceous, creeping, non-climbing legume that reaches 0.6 to $1.2 \mathrm{~m}$ in height (Pereira, 2008). This species was chosen because it is commonly used in the control of soil erosion and in projects involving recovery of degraded areas. It grows easily and is adaptable to adverse environmental conditions (Erasmo et al., 2004; Faria et al., 2004; Nascimento \& Silva, 2004; Fontanétti et al., 2006; Pereira 2008). In this study the effect of fertirrigation was assessed, using different wastewater concentrations during the initial, vegetative and reproductive development of $C$. ensiformis.

To assess the $C$. ensiformis initial development, an independent experiment was carried out for 16 days, period during which seedlings emergence and vigor. In this experiment, seeds germinated in a 300-mL disposable plastic cup (Figure 1A), filled, from bottom to top, with $1 \mathrm{~cm}$-thick layer of artificial gravel, $1 \mathrm{~cm}$-thick layer of sand, and a Plintosol-type, horizon A soil from the Urutaí Campus. The parameters analyzed were: germination rate (GR), germination speed index (GSI) (according to Maguire 1962), germination mean time (GMT) (according to Silva \& Nakagawa (1995), fresh phytomass of the aerial parts, roots and total phytomass.

To assess the $C$. ensiformis vegetative and reproductive development, another experiment was carried out for 130 days, where 12-L plastic vases were used (Figure 1B) with a hole at the bottom and filled with a $3 \mathrm{~cm}$-thick layer of artificial gravel and $8 \mathrm{~kg}$ of soil from an area affected by severe erosion. The following parameters were analyzed every 15 days: length of the aerial part, the diameter of the stalk, total number of leaves and ramifications per plant. On the $130^{\text {th }}$ day, dry and fresh phytomass of the aerial parts, roots and total phytomass and the number of pods produced per plant were computed. The number of flower buds was also obtained, when flowering occurred during the experiment.

To assess the $C$. ensiformis initial development, a completely randomized design was adopted, with five treatments and 30 repetitions. To assess vegetative and reproductive development, a completely randomized design was adopted, with five treatments and eight repetitions. For both evaluations, the treatments consisted of: L100 (100\% wastewater coming from the domestic sewage stabilization pond - A.R.); A100 (100\% supply water - A.A.); L75 (75\% A.R.+ $25 \%$ A.A.); L50 (50\% A.R. + 50\% A.A.), and L25 (25\% A.R. $+75 \%$ A.A.). Fertirrigation was carried out daily, being enough to moist the substrate at field capacity.

In each experiment, the same volume of water was used in all treatments. It was estimated using the Hargreaves-Samani method, which takes into account evapotranspiration (Etc) - the crop coefficient (kc) being a function of the phenological stage of the plant - and the reference evapotranspiration (Et0), which is a function of the local climatic demand.

For the chemical characterization of the irrigation/fertirrigation waters, the concentrations of the following elements were determined: $\mathrm{Al}, \mathrm{Ba}, \mathrm{Ca}, \mathrm{Fe}, \mathrm{K}$, $\mathrm{Mg}, \mathrm{Mn}, \mathrm{P}$ and $\mathrm{S}$. During the whole experimental peri-
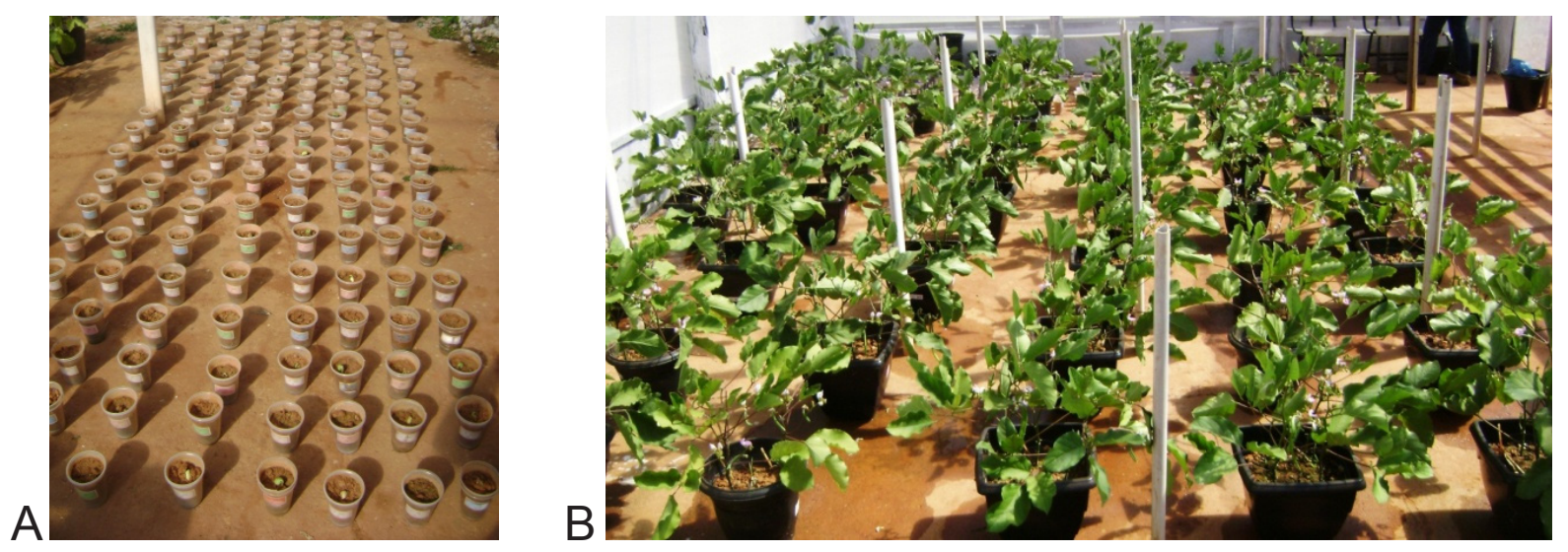

Figure 1 - Experiments to evaluate initial (A), vegetative and reproductive (B) development of $C$. ensiformis, performed in a greenhouse at the Instituto Federal Goiano - Campus Urutaí (Goiás, Brazil). 
od, an aliquot $(100 \mathrm{~mL}$ ) of irrigation/fertirrigation waters was collected daily and kept in a freezer. By the end of the experiment, these aliquots constituted a composite sample, which was analyzed by ICP-OES (Inductively Coupled Plasma Optical Emission Spectrometry) at the Laboratory of Environmental Geochemistry of the Universidade Federal de Ouro Preto (Minas Gerais, Brazil). After the 130-day experimental period, soil samples from each experimental group were collected and analyzed for: P, K, Ca, Mg, Ca + Mg, CTC, $\mathrm{Cu}, \mathrm{Fe}, \mathrm{Mg}$ and $\mathrm{Zn}$. Soil analyses were performed by a commercial laboratory in Goiânia (Goiás, Brazil), following the recommendations from the Brazilian Agricultural Research Corporation (Empresa Brasileira de Pesquisa Agropecuária - EMBRAPA, 1997).

The resulting data were treated using the analysis of variance method. The Tukey test was used to compare mean values at $5 \%$ probability.

\section{RESULTS AND DISCUSSION}

The parameters GSI, GMT and GR obtained for the $C$. ensiformis initial development are listed in Table 1 , including height of the seedlings and the fresh phytomass of the aerial part, roots and total phytomass. No significant statistical differences were found between the five groups (Figures $2 \mathrm{~A}$ and $2 \mathrm{~B}$ ).

It is worth mentioning that studies involving different vegetal species have shown that the initial development of a plant is influenced by several factors, including temperature, soil moisture, seed dormancy, seed storage conditions, age of the seeds, and presence or absence of light (Felippee-Polo, 1983; Mikusinski, 1987; Klein and Felippe, 1991). The results obtained in this study reveal that the irrigation with wastewater did not affect the initial development of $C$. ensiformis. This means that the quantity, rather than the quality, of water is important at this stage. In principle, seeds need moist to soften and break the integument. This process allows the access of oxygen to the embryonic cells, thus starting the imbibition phenomenon (Borges \& Rena, 1993; Bewley \& Black, 1994). According to Corte et al. (2006), water that enters the seed promotes metabolic reactions that mobilize the energy reserves contained in the seed itself, in the cotyledons or endosperm, making energy available to the cells. Therefore, the seed does not need external nutrient or energy sources, which explains the fact that the treatments employed in the experiments did not influence the parameters related to the initial development of $C$. ensiformis.

However, it is an understatement to state that the concentration of nutrients in the soil is not important to the initial development of a species. Mota et al. (2011),
Table 1 - Germination rate (GR), germination speed index (GSI) e germination mean time (GMT), corresponding to the initial development of Canavalia ensiformis*

\begin{tabular}{cccccc}
\hline \hline \multirow{2}{*}{ Variables } & \multicolumn{5}{c}{ Experimental groups } \\
\cline { 2 - 6 } & $\mathbf{A 1 0 0}$ & $\mathbf{L 1 0 0}$ & $\mathbf{L 7 5}$ & $\mathbf{L 5 0}$ & $\mathbf{L 2 5}$ \\
\hline GSI & 3.2 & 3.3 & 2.7 & 2.7 & 2.0 \\
GMT & 6.9 & 6.8 & 7.5 & 7.1 & 7.5 \\
GR (\%) & 70.0 & 70.0 & 63.3 & 60.0 & 50.0 \\
\hline \hline
\end{tabular}

studying the development of crimson sweet cuttings irrigated with different concentrations of domestic sewage wastewater, observed positive effects on the development of the species. The authors attested by the $F$ test the significantly better effect $(p<0.05)$ on TG, IVG, number of leaves and fresh matter of the aerial part. Despite not discussing their results, when comparing them with other data from the available literature, which demonstrate that at initial stages the energy in the seeds is more important than the nutrients in the soil, we believe that the results obtained by Mota et al. (2011) can be explained by the high organic matter concentration present in the irrigation waters. In this case, this organic matter concentration would allow a higher retention of water in the soil.

Regarding the length of the plants, which was measured every 15 days during the experimental period, it was observed that the period of highest growth rate was between the $15^{\text {th }}$ and the $75^{\text {th }}$ day after sowing. From the $75^{\text {th }}$ day to the end of the experiment, groups $L 100$ and $L 75$ were the longest $(p<0.05)$, when compared to group A100 (Figure 2C).

Regarding the diameter of the stalk, from the $75^{\text {th }}$ day of the experiment, group L100 yielded higher statistical values than group A100 (Figure 2D), and from the $90^{\text {th }}$ day, group $L 75$ also yielded higher values than group A100. These differences remained until the end of the experiment (Figure 2D). It is worth mentioning that for both length of the plant and diameter of stalk, from the $75^{\text {th }}$ day on, group A100 yielded the lowest values when compared to the other groups. Similar results were found for total number of leaves and ramifications (graphs not shown).

Fideles-Filho et al. (2005), studying the influence of irrigation with wastewater on the development of cotton, observed that height of the plant and diameter of the stem reached the highest values in groups irrigated with effluents. According to the authors, these results are related to the quality of the wastewater, which is usually rich in nutrients used by the plants to grow and develop. Alves et al. (2009a), analyzing the effect of the application of wastewater on the growth of brown fiber cotton, also observed that the plants irrigated with wastewater were taller than those irrigated with supply water. Souza et al. (2010a), when assessing the diameter of the stem, had better results in treatments 
in which the species Ricinus communis $L$. (castor oil plant) was irrigated with wastewater.

Regarding the reproduction parameters, irrigation with $100 \%$ wastewater (group L100) promoted the growth of a larger number de flower buds (Figure $3 \mathrm{~A}$ ), as well as a larger number of pods per plant (groups L100 and L75) in comparison to irrigation with supply water or other wastewater concentrations (Figure 3B). Similar results were found by Medeiros et al. (2007), when assessing the use of wastewater in gerbera crops. The authors observed that not only a larger number of flower buds and flowers grew, but also the time to form buds and the time interval between crops were shorter.

In the present study, the fresh and dry phytomass of the aerial parts, roots and total phytomass of the groups irrigated with wastewater were also evaluated. The results obtained for the fresh and dry phytomass of the aerial parts and total phytomass revealed higher values $(p<0.05)$ for treatments $L 100$ and L75, when compared to the other groups (Figures $3 \mathrm{C}$ and $3 \mathrm{D}$ ), which may be a consequence of higher nutrient concentrations in wastewater.

In order to understand the results found in groups irrigated with wastewater, especially L100 and L75, a chemical characterization of the waters used in the irrigation of the crops was carried out. Table 2
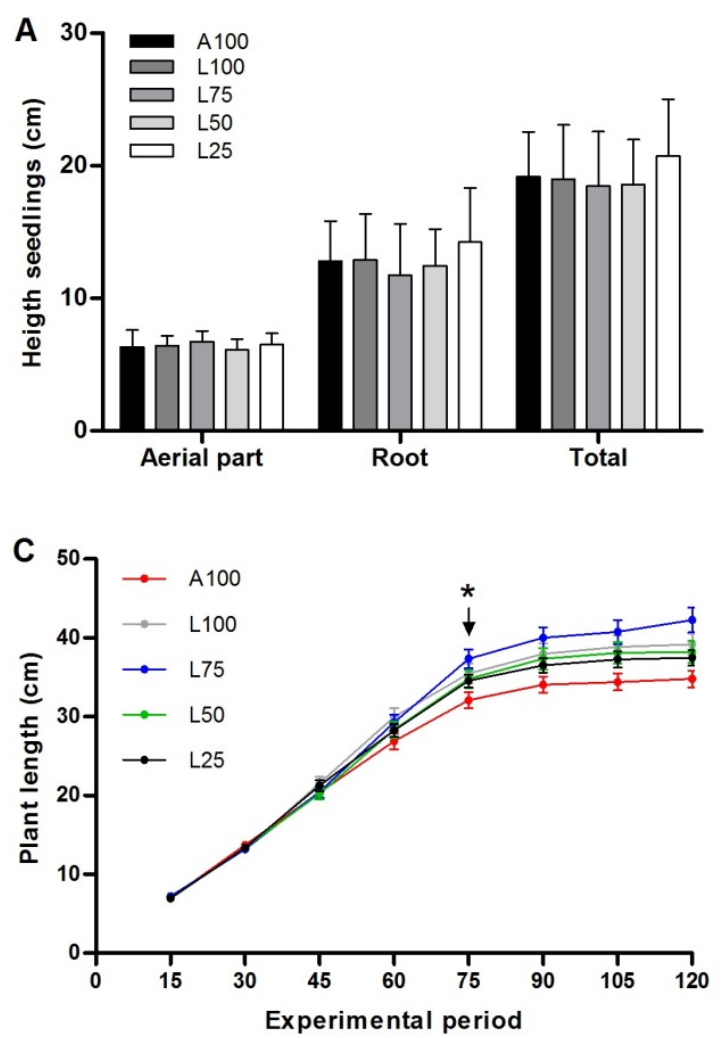

shows that the waters used in the irrigation of groups $\mathrm{L} 100$ and $\mathrm{L} 75$ yielded the highest $\mathrm{Ca}, \mathrm{Mg}, \mathrm{K}$ and $\mathrm{P}$ contents, which can explain the better performance of the crops irrigated with $100 \%$ and $75 \%$ wastewater concentrations. Especially regarding $\mathrm{P}$ and $\mathrm{K}$, the highest concentrations of these elements in wastewater coincide with the highest concentrations found in soils after 130 days (Table 2). These macronutrients are of fundamental importance to the vegetative and reproductive development of the plant.

Potassium, in particular, is present in all tissues and is indispensable for the plant healthy development. According to Veiga et al. (2010), its main functions are related to the enzymatic activation, the translocation of assimilates, nitrogen uptake and protein and starch synthesis. Filho et al. (2010) state that $\mathrm{K}$ is also required for the activation of many enzymes responsible for respiration and photosynthesis.

Phosphorous is another important element and it is the most used nutrient in manuring in Brazil, due to its scarcity in Brazilian soils (Holanda, 1995). Phosphorous is extremely important to vegetables and it is found in cellular DNA and RNA. A deficiency in P causes a dark green coloration of older leaves, due to a purple coloration coming from the accumulation of anthocyanin (Filho et al., 2010).
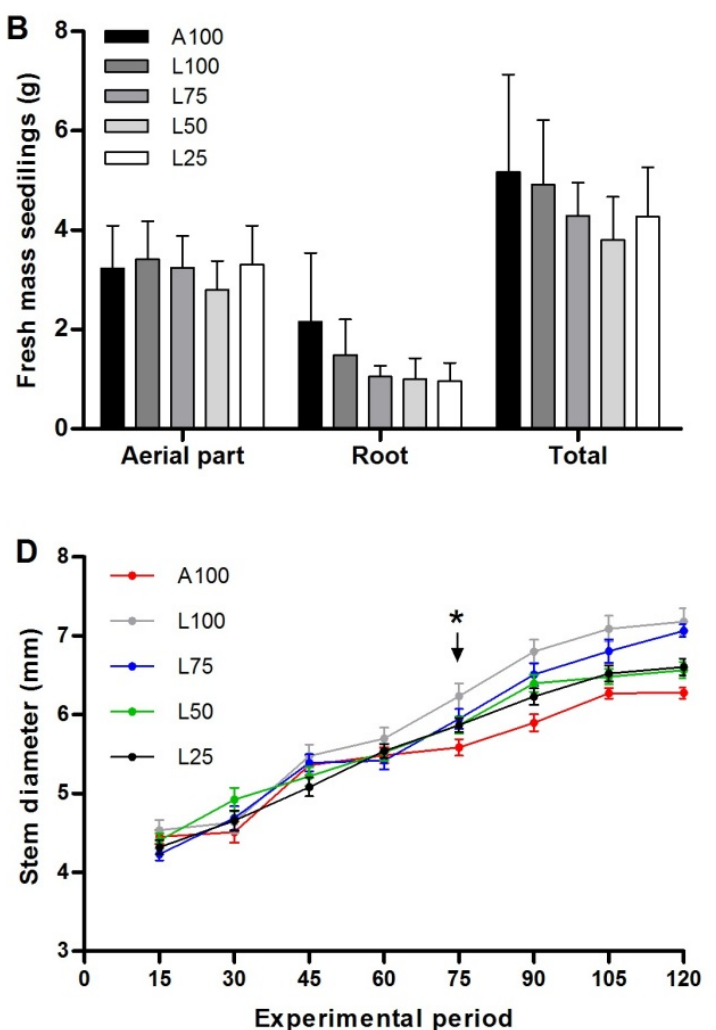

Figure 2 - (A) Height (in cm) of the seedlings; (B) humid phytomass (in g) of the seedlings; (C) length of the plants (in $\mathrm{cm}$ ); (D) diameter of the stalk (in $\mathrm{mm}$ ), along the experimental period. Asterisk indicates the moment (day) in which a significant statistical difference starts between groups L75 and A100. Bars indicate mean values + standard deviation (A and B). Points indicate mean values $+/-$ standard deviation (C and $\mathrm{D})$. 
Table 2 - Concentrations of some chemical elements in water used for irrigation of crops and in soil samples.

\begin{tabular}{|c|c|c|c|c|c|c|c|c|c|}
\hline \multicolumn{10}{|c|}{ Concentrations of elements in irrigation waters } \\
\hline Groups & $\begin{array}{c}\mathrm{Al} \\
(\mu \mathrm{g} / \mathrm{L})\end{array}$ & $\begin{array}{c}\mathrm{Ba} \\
(\mu \mathrm{g} / \mathrm{L})\end{array}$ & $\begin{array}{c}\mathrm{Ca} \\
(\mathrm{mg} / \mathrm{L})\end{array}$ & $\begin{array}{c}\mathrm{Fe} \\
(\mu \mathrm{g} / \mathrm{L})\end{array}$ & $\begin{array}{c}\mathrm{K} \\
(\mathrm{mg} / \mathrm{L})\end{array}$ & $\underset{(\mathrm{mg} / \mathrm{L})}{\mathrm{Mg}}$ & $\underset{(\mu \mathrm{g} / \mathrm{L})}{\mathrm{Mn}}$ & $\begin{array}{c}P \\
(\mathbf{m g} / L)\end{array}$ & $\begin{array}{c}\mathrm{S} \\
(\mathrm{mg} / \mathrm{L})\end{array}$ \\
\hline A100 & 92.3 & 11.5 & 5.26 & 59.6 & 2.38 & 2.95 & 2.32 & $<\mathrm{LQ}$ & 1.57 \\
\hline L100 & 76.8 & 9.87 & 11.4 & 234 & 14.7 & 4.58 & 54.2 & 1.76 & 2.96 \\
\hline L75 & 80.7 & 10.3 & 9.9 & 190.4 & 11.6 & 4.2 & 41.2 & 1.3 & 2.6 \\
\hline L50 & 84.6 & 10.7 & 8.3 & 146.8 & 8.5 & 3.8 & 28.3 & 0.9 & 2.3 \\
\hline L25 & 88.4 & 11.1 & 6.8 & 103.2 & 5.5 & 3.4 & 15.3 & 0.4 & 1.9 \\
\hline Quantification limit & 9.51 & 0.348 & 0.0130 & 7.98 & 0.0716 & 0.00155 & 1.17 & 0.0890 & 0.0644 \\
\hline \multicolumn{10}{|c|}{ Concentrations of elements in soil samples } \\
\hline \multicolumn{4}{|c|}{ Parameters } & Untreated soil & A 100 & L 25 & L 50 & L 75 & L 100 \\
\hline \multicolumn{4}{|c|}{$P\left(\mathrm{mg} / \mathrm{dm}^{3}\right)$} & 10 & 1 & 4 & 5 & 11 & 13 \\
\hline \multicolumn{4}{|c|}{$\mathrm{K}\left(\mathrm{mg} / \mathrm{dm}^{3}\right)$} & 320 & 60 & 88 & 116 & 200 & 200 \\
\hline \multicolumn{4}{|c|}{$\mathrm{Ca}\left(\mathrm{mEq} / 100 \mathrm{~cm}^{3}\right)$} & 6.7 & 3.0 & 4.2 & 3.7 & 4.4 & 5.3 \\
\hline \multicolumn{4}{|c|}{$\mathrm{Mg}\left(\mathrm{mEq} / 100 \mathrm{~cm}^{3}\right)$} & 3.4 & 1.9 & 2.8 & 2.7 & 3.0 & 3.3 \\
\hline \multicolumn{4}{|c|}{$\mathrm{Ca}+\mathrm{Mg}\left(\mathrm{mEq} / 100 \mathrm{~cm}^{3}\right)$} & 10.1 & 4.9 & 7.0 & 6.4 & 7.4 & 8.6 \\
\hline \multicolumn{4}{|c|}{ CTC $\left(\mathrm{mEq} / 100 \mathrm{~cm}^{3}\right)$} & 11.8 & 5.8 & 7.8 & 7.2 & 8.5 & 9.7 \\
\hline \multicolumn{4}{|c|}{$\mathrm{Cu}\left(\mathrm{mg} / \mathrm{dm}^{3}\right)$} & 3.3 & 2.9 & 2.9 & 3.0 & 3.0 & 3.8 \\
\hline \multicolumn{4}{|c|}{$\mathrm{Fe}\left(\mathrm{mg} / \mathrm{dm}^{3}\right)$} & 131 & 104 & 94 & 116 & 98 & 97 \\
\hline \multicolumn{4}{|c|}{$\mathrm{Mg}\left(\mathrm{mg} / \mathrm{dm}^{3}\right)$} & 30 & 28 & 23 & 26 & 24 & 25 \\
\hline \multicolumn{4}{|c|}{$\mathrm{Zn}\left(\mathrm{mg} / \mathrm{dm}^{3}\right)$} & 1.6 & 1.8 & 0.6 & 1.1 & 1.8 & 1.1 \\
\hline
\end{tabular}

In summary, the $\mathrm{P}$ and $\mathrm{K}$ concentrations found in treatments $L 100$ and $L 75$ can contribute to a possible decrease in the use of phosphatic and even potassic fertilizers, which can also reduce costs and contaminants in the soil. Regarding $\mathrm{P}$ specifically,
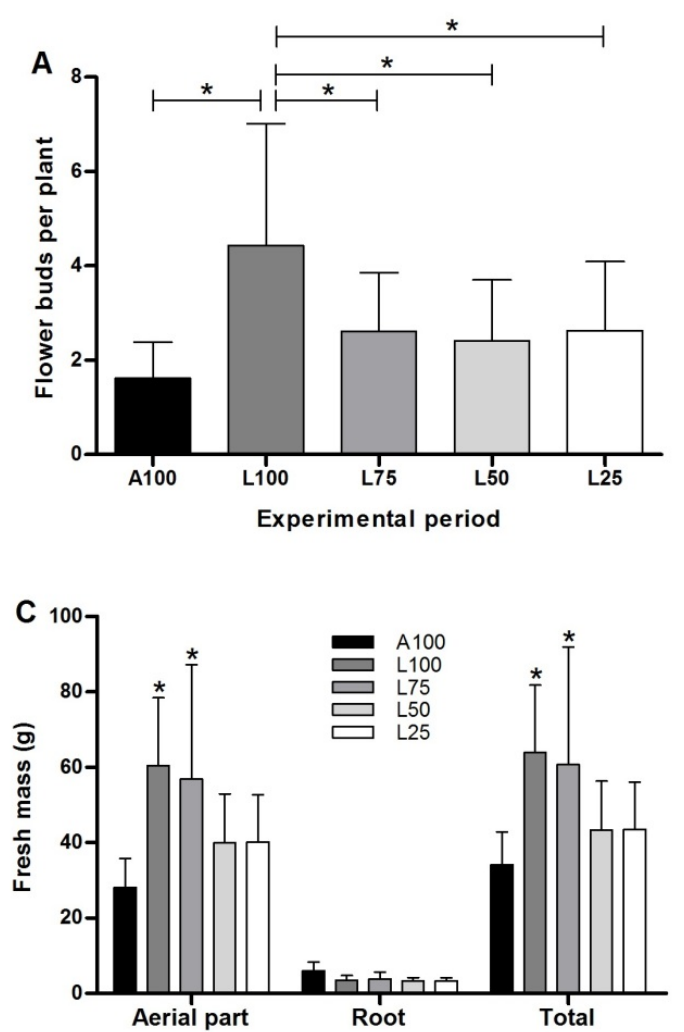

treatments $L 100$ and $L 75$ promoted an increase of $P$ concentration in the soil (Table 3 ). As P concentrations available in weathered soils of natural ecosystems are low, several mechanisms are adopted by plants and organisms to increase efficiency in absorbing $P$.
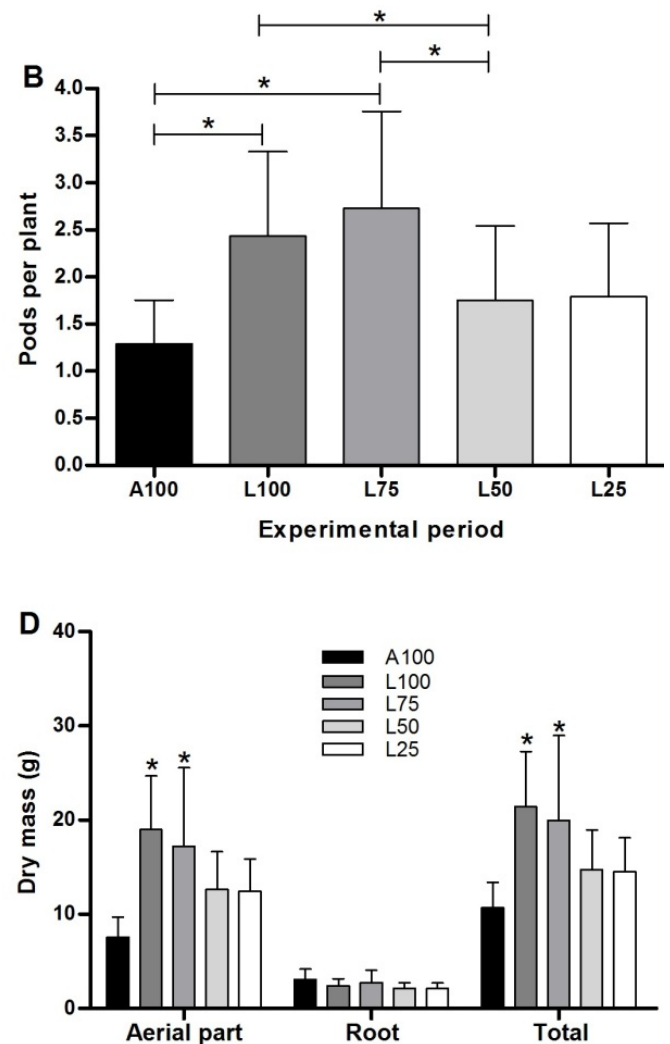

Figure 3 - (A) Flowers buds per plant, (B) average number of pods per plant, (C) fresh mass and (D) dry mass at the end of the experiment. The bars indicate the mean + the standard deviation data. Asterisks indicate statistically significant differences between groups L75 and L100 in the other groups $(p<0.05)$. Analyses of variance and comparisons of means were made by Tukey test at $5 \%$ probability. 
Investments in fertilizers and liming are necessary to increase the availability and absorption of phosphorous by the plants (Gatiboni et al., 2003).

Even if wastewater alone is not capable of supplying all the $C$. ensiformis nutritional needs, it can be an additional tool in fertilization. Considering that $\mathrm{P}$ and $\mathrm{K}$ are the main fertilizing elements and are extensively added to agricultural fertilizers, we believe that the results shown here are promising and open perspectives to the use of waters derived from domestic sewage as a possible source of elements rather than industrialized chemical fertilizers. These results are even more promising when one considers that the soils of the Cerrado biome are of low natural fertility and present high $\mathrm{P}$ fixation capacity.

\section{CONCLUSIONS}

that:

Based on the exposed above, we can conclude

- The use of wastewater in C. ensiformis crop irrigation does not affect the initial development of the species;

- The increase in domestic wastewater content in irrigation waters increased the production of fresh and dry material of the aerial parts and total phytomass, as well as the length of the plant, diameter of the stalk, number of leaves, number of ramifications, number of flower buds and pods. These results emphasize the proportional vegetative and reproductive development of the plants.

- Lacking mineral manuring, soils from groups L100 and L75 irrigated with high concentrations of wastewater ( $100 \%$ and $75 \%$, respectively) can supply $\mathrm{K}$ and $P$ for the $C$. ensiformis nutritional demands.

\section{REFERENCES}

Alves, W.W.A.; Azevedo, C A.V.; Neto, J.D.; De-Lima, V.L.A. \& Sousa, J.S.C. 2009a. Altura da planta do algodoeiro de fibra marrom irrigado com água residuária doméstica tratada. RVADS. 4(1): 28-32.

Alves, W.W.A.; Azevedo, C.A.V.; Neto, J.D.; De-Sousa, J.T. \& Lima, V.L.A. 2009b. Água residuárias e nitrogênio: efeito na cultura do algodão marrom. RVADS 4(1): 16-23.

Azevedo, M.E.Q.A.; König, A.; Beltrão, N.E. de. M.; Azevedo, C.A.V.; Tavares, T.L. \& Soares, F.A.L. 2007. Efeito da irrigação com água residuária tratada sobre a produção de milho forrageiro. Rev. Bras. Ciênc. Agrár. 2(1): 63-68.

Azevedo, J.; Durtra, I.C.B.; Costa, F.G.B.; Batista, R.O. \& Costa, L.R. 2013. Alterações químicas de cambissolo fertirrigado com água residuária doméstica tratada. Agropec. Cien. Semiárido. 9(2): 66-76.

Bewley, J.D. \& Black, M. 1994. Seeds: Physiology of development and germination. $2^{\circ}$ Edição. New York: Plenum Press, 90p.

Borges, E.E.L. \& Rena, A.B. 1993. Germinação de sementes. In: Aguiar, I. B.; Piña-Rodrigues, F.C.M. \& Figliolia, M.B. (Ed.). Sementes florestais tropicais. Brasília: ABRATES. 83-136pp.

Corte, V.B. et al. 2006. Mobilização de reservas durante a germinação das sementes e crescimento das plântulas de Caesalpinia peltophoroides Centh. (Leguminosae-Caesalpinoideae). Rev. Árvore. 30(6): 941-949.

Costa, F.X., Lima, V.L.A.; Beltrão, N.E.; Azevedo, C.A.V.; Soares, F.A.L. \& Alva, I. D. M. 2009. Efeitos residuais da aplicação do biossólido e da irrigação com água residuária no crescimento do milho. Rev. Eng. Agríc. e Ambient. 12(1): 687-693.

Damasceno, L.M.O.; Andrade-Jr, A.S.; Gheyih., R.; Sias, N.S. \& Silva, C.O. 2011. Composição nutricional foliar da gérbera irrigada com efluente doméstico tratado. Rev. Caatinga. 24(2): 121-128.

Empresa Brasileira de Pesquisa Agropecuária (EMBRAPA). 1997. Manual de métodos de análise de solo. Centro Nacional de Pesquisa de Solos. Edição. Rio de Janeiro: EMBRAPA, 1997.

Erasmo, E.A.L.; Azevedo, W.R.; Sarmento, R.A.; Cunha, A.M. \& Garcia, S.L.R. 2004.Potencial de espécies utilizadas como adubo verde no manejo integrado de plantas daninhas. Planta Daninha. 22(3): 337-342.

Erthal, V.J.T.; Ferreira, P.A.; Matos, A.T. \& Pereira, O.G. 2010. Alterações físicas e químicas de um Argissolo pela aplicação de água residuária de bovinocultura. Rev. Bras. Eng. Agríc. Ambient. 14(5): 467-477.

Faria, C.M.B.; Soares, J.M. \& Leão, P.C.S. 2004. Adubação verde com leguminosas em videira no submédio São Francisco. Rev. Bras. Ciên. Solo. 28(4): 641-648.

Felippe, G.M. \& Polo, M. 1983. Germinação de ervas invasoras: efeito da luz e escarificação. Rev. Bras. Bot. 6(1): 55-60.

Fideles-Filho, J.; Nóbrega, J.Q.; Sousa, J.T. \& Dantas, J.P. 2005. Comparação dos efeitos de água residuária e de poço no crescimento e desenvolvimento do algodoeiro. Rev. Bras. Eng. Agríc. Ambient. 9(Suppl 1): 328-332.

Filho, J.E.; Miranda, M.R.A. \& Silveira, J.A.G. 2010. Nutrição mineral de plantas. Ceará: Universidade Federal do Ceará, 2010.

Fontanétti, A.; Carvalho, G.J.; Gomes, L.A.A.; Almeida, K.; Moraes, S.R.G. \& Teixeira, M. 2006. Adubação 
verde na produção orgânica de alface americana e repolho. Hortic. Bras. 24(2): 146-150.

Galli, J.A.; Silveira, L.C.P.; Michelotto, M.D. \& Martins, A.L.M. 2009. Avaliação da incidência de antracnose, do desempenho e estado nutricional de variedades de mangueira, para cultivo orgânico, na região centro-norte do estado de São Paulo. Rev. Bras. Frutic. 31(3): 701-709.

Gatiboni, L.C. 2003. Disponibilidade de formas de fósforo do solo às plantas. 2003. Tese de Doutorado em Agronomia. Universidade Federal de Santa Maria, UFSM, 247p.

Hespanhol, I. 2003. Potencial de reuso no Brasil: agricultura, indústria, município e recarga de aqüíferos. In: Mancuso, P.C.S. \& Santos, H.F. dos (Ed.). Reuso de água. São Paulo: Manole. 37-95pp.

Holanda, J.S.; Brasil, E.C.; Salviano, A.A.C.; Carvalho, M.C.S.; Rodrigues, M.R.L. \& Malavolta, E. 1995. Eficiência de extratores de fósforo para um solo adubado com fosfatos e cultivado com arroz. Sci. Agric. (Piracicaba, Braz.). 52(3): 561-568.

Javarez-Junior A., Ribeiro T.A.P., De Paula Jr. D.R. 2010. Eficiência do reuso de águas residuárias na irrigação da cultura do milho. Irriga 15(3): 231-247.

Klein, A. \& Felippe, G.M. 1991. Efeito da luz na germinação de sementes de ervas invasoras. Pesq. Agropec. Bras. 26(7): 955-66.

Lacerda, P.M. de; Rodrigues, R.F.; Nalini-Júnior, H.A.; Malafaia, G. \& Rodrigues, A.S.L. 2011. Influência da irrigação com águas residuárias no desenvolvimento de Canavalia ensiformis (feijão-de-porco). Rev. Acad., Agrár. Ambient. 9(1): 159-168.

Maguire, J.D. 1962. Speed of germination-aid in selection and evaluation for seedling emergence and vigour. Crop Science. 2(2): 176-177.

Medeiros, S.S.; Soares, F.A.L.; Ghey, H.R. \& Fernandes, P.D. 2007. Uso de água residuária de origem urbana no cultivo de gérberas: efeito nos componentes de produção. Eng. Agríc. 27(2): 569-578.

Mikusinski, O.M. 1987. Testes de embebição e germinação em sementes de Ipomoea aristolochiaefolia. Rev. Bras. Sem. 9(3): 103-108.

Moreira, T.C.L. 2010. Interação da poluição atmosférica e a vegetação arbórea na cidade de São Paulo. Dissertação de Mestrado em Ciências. Escola Superior de Agricultura "Luiz de Queiroz". Universidade de São Paulo, Piracicaba, 2010. 81p.

Mota, A.F.; Almeida, J.P.N.; Santos, J.S.; Azevedo, J. \& Gurgel, M.T. 2011. Desenvolvimento inicial de mudas de melancia 'crimson sweet' irrigadas com águas residuárias. RVADS 6(2): 98-104.
Nascimento, J.T. \& Silva, I.F. 2004. Avaliação quantitativa e qualitativa da fitomassa de leguminosas para uso como cobertura de solo. Ciênc. Rural. 34(3): 947-949.

Nascimento, M.B.H.; Lima, V.L.A.; Azevedo, C.A.V. \& Souza, A.F. 2009. Propriedades químicas do solo cultivado com mamona, irrigado com água residuária tratada de adubado com biossólido. RVADS 4(1): 8-15.

Nery-Rodrigues L.; Nery A.R.; Fernandes, P.D. \& Beltrão, N.E.M. 2009. Aplicação de água residuária de esgoto doméstico e seus impactos sobre a fertilidade do solo. Rev. Biol. Ciênc. Terra. 9(2): 55-67.

Oliveira, P.C.P.; Gloaguen, T.V.; Gonçalves, R.A.B. \& Santos, D.L. 2013a. Produção de moranga irrigada com esgoto doméstico tratado. Rev. Bras. Eng. Agríc. Ambient. 17(8): 861-867.

Oliveira, N.M.; Silva, M.P. \& Carneiro, V.A. 2013b. Reuso da água: um novo paradigma de sustentabilidade. Élisée: Rev. Geog. UEG 2(1): 146-157.

Pereira, A.R. 2008. Como selecionar plantas para áreas degradadas e controle de erosão. Disponível em: http://biologybrasil.blogspot.com/2009/08/ como-selecionar-plantas-para-areas.html. Acesso em 20 de abril de 2010.

Raij, V. \& Bataglia, C. 1991. Análise química de solo. In: Ferreira, M.E.; Cruz, M.C.P (Ed). Micronutrientes na agricultura. Piracicaba: Potafos/ CNPq, 435-444pp.

Sampaio, P.R.F.; Almeida, J.P.N.; Mota, A.F.; Costa, L.R. \& Gurgel, M.T. 2011. Utilização de águas residuárias na germinação e desenvolvimento inicial de mudas de meloeiro 'amarelo ouro'. RVADS 6(1): 179 -187.

Santos-Junior, J.A.; Gheyi, H.R.; Dias, N.S.; Soares, F.A.L. \& Nobre, R.G. 2011. Doses de boro e água residuária na produção do girassol. Rev. Ciênc. Agron. 42(4): 857-864.

Silva, J.B.C. \& Nakagawa, J. 1995. Estudo de fórmulas para cálculo da velocidade de germinação. Informativo ABRATES 5(1): 62-73.

Silva, A.S.; Laime, E.M.; Souza, R.N.; Filho, L.T.S. \& Oliveira, D.C.S. 2012. Caracterização de plantas de milho na absorção de nutrientes e metais pesados pós submissão à irrigação com efluentes. Rev. Educ. Agríc. Sup. 27(2): 141-145.

Sousa, J.T.; Ceballos, B.S.O.; Henrique, I.N.; Dantas, J.P. \& Lima, S.M.S. 2006. Reúso de água residuária na produção de pimentão (Capsicum annuum L.). Rev. Bras. Eng. Agríc. Ambient. 10(1): 89-96.

Souza, N.C.; Mota, S.B.; Bezerra, F.M.L.; Aquino, B.F. \& Santos, A.B. 2010a. Produtividade da mamona irrigada com esgoto doméstico tratado. Rev. Bras. Eng. Agríc. Ambient. 14(5): 478-484. 
Souza, J.A.A.; Batista, R.O.; Ramos, M.M. \& Soares, A.A. 2010b. Alteração nas características físicas do solo decorrentes da aplicação de esgoto doméstico tratado. Acta. Sci. Technol. 32(4): 361-366.

Vale, H.S.M.; Arruda, L.E.V.; Costa, D.O.; Costa, F.G.B. \& Batista, R.O. 2013. Potencial de entupimento de um sistema de irrigação por gotejamento operando com esgoto doméstico tratado. Water Resour. Irrig. Manag. 2(1): 63-70.
Veiga, A.D.; Pinho, E.V.R.V.; Veiga, A.D.; Pereira, P.H.A.R.; Oliveira, K.C. \& Pinho, R.G.V. 2010. Influência do potássio e da calagem na composição química, qualidade fisiológica e na atividade enzimática de sementes de soja. Ciênc. Agrotec. 34(4): 953-960. 